SHEs: Conference Series 3 (2) (2020) 43 - 49

\title{
Pancasila Values Education in Learning History in Indonesia
}

\author{
Erisya Pebrianti Pratiwi \\ Universitas Sebelas Maret \\ erisya27@student.uns.ac.id
}

\section{Article History}

accepted 1/09/2020

approved 4/10/2020

published 1/12/2020

\begin{abstract}
Multicultural education with Pancasila values aims to change schools, so that all students can learn about the knowledge, attitudes and skills needs to be applied in countries and worlds that have different races and cultures. Multicultural education with Pancasila values as a new discourse in Indonesia can be implemented not only through formal education, but can also be implemented in daily life in the community as well as in families (nonformal and informal education). In multicultural education, some dimensions need to be considered as well as facts that need to be put forward in connection with the outbreak of conflict in society that if not immediately addressed will be more protracted. Multicultural education can be implied in the world of education where there are seven ways in this article. In implementing Pancasila values with multicultural education in students in schools, as educators and teachers will encounter obstacles or challenges in their implementation. The innovation of historical learning is required in historical subjects in shaping the character of students.
\end{abstract}

Keywords: Education, multicultural, Pancasila

\begin{abstract}
Abstrak
Pendidikan multikultural dengan nilai-nilai pancasila bertujuan untuk merubah sekolah, sehingga semua siswa dapat belajar mengenai pengetahuan, sikap dan kebutuhan keahlian untuk diterapkan dalam negara dan dunia yang memiliki bermacam-macam ras serta budaya. Pendidikan multikultural dengan nilai-nilai pancasila sebagai wacana baru di Indonesia dapat dilaksanakan tidak hanya melalui pendidikan formal, namun juga dapat diimplementasikan dalam kehidupan sehari-hari di masyarakat maupun dalam keluarga (pendidikan nonformal dan informal). Dalam pendidikan multikultural, ada dimensi-dimensi yang harus diperhatikan dan juga fakta yang perlu dikemukakan sehubungan dengan merebaknya konflik dalam masyarakat yang jika tidak segera diatasi akan semakin berlarut-larut. Pendidikan multikultural dapat diimplikasikan dalam dunia pendidikan di mana terdapat tujuh cara dalam artikel ini. Dalam mengimplementasikan nilai-nilai pancasila dengan pendidikan multikultural pada peserta didik di sekolah pun, sebagai pendidik dan pengajar akan menemui hambatan atau tantangan dalam pelaksanaannya. Adanya inovasi pembelajaran sejarah diperlukan dalam mata pelajaran sejarah dalam membentuk karakter peserta didik.
\end{abstract}

Kata kunci: Pendidikan, multikultural, Pancasila

\author{
Social, Humanities, and Education Studies (SHEs): Conference Series p-ISSN 2620-9284 \\ https://jurnal.uns.ac.id/shes \\ e-ISSN 2620-9292
}




\section{PENDAHULUAN}

Multikulturalisme adalah aspek yang tidak terbantahkan bagi seluruh masyarakat Indonesia, entah hal itu disadari atau tidak. Multikulturalisme menunjukkan suatu yang krusial dalam dunia kontemporer. Dalam dunia multikultural harus mementingkan adanya berbagai macam perbedaan antara yang satu dengan yang lainnya dan ada interaksi sosial di antara mereka (Brian Fay, 1998: 3-4). Di Indonesia kesadaran untuk hidup rukun antar warga negara yang berbeda, termasuk perbedaan agama, hendaknya berpedoman pada nilai-nilai Pancasila. Hendaknya pula dapat dikaitkan dengan tingkat kesadaran masyarakat akan pendidikan, yang dibarengi dengan tingkat kesadaran akan "hakekat" dari kehidupan (Agung, 2017: 155).

Pendidikan di Indonesia sendiri mulai kehilangan rohnya dari tujuan pendidikan nasional yang ditekankan oleh Bapak Pendidikan Nasional Ki Hajar Dewantara bahwa pendidikan merupakan daya upaya, untuk memajukan pertumbuhan budi pekerti yang meliputi kekuatan batin atau karakter, pikiran atau intelektual dan tubuh anak (Andarwati, 2017: 173). Nilai-nilai kebersamaan, toleransi, serta mampu menyesuaikan diri dengan perbedaan harus ditanamkan di sekolah. Proses pendidikan ke arah ini dapat ditempuh dengan pendidikan multikultural. Pendidikan multikultural merupakan proses penanaman cara hidup menghormati, tulus, dan toleran terhadap keberagaman budaya yang hidup di tengah-tengah masyarakat plural.

Sekolah memegang peranan penting dalam menanamkan nilai multikultural pada siswa sejak dini. Jika sejak awal mereka telah memiliki nilai-nilai bersamaan, toleran, cinta damai, dan menghargai perbedaan, maka nilai-nilai tersebut akan tercermin pada tingkah laku mereka sehari-hari karena terbentuk pada kepribadiannya (Arifudin, 1970: 2). Lewat penanaman semangat multikulturalisme di sekolah-sekolah, akan menjadi media pelatihan dan penyadaran bagi generasi muda untuk menerima perbedaan budaya, agama, ras, etnis, dan lainnya di antara sesama serta mau hidup bersama secara damai. Agar proses ini dapat berjalan lancar, maka seharusnya kita mau menerima jika pendidikan multikultural disosiaisasikan melalui lembaga pendidikan, dan jika perlu dapat diterapkan sebagai bagian dari kurikulum pendidikan di berbagai jenjang dan jenis pendidikan (Ambarudin, 2016: 36-37).

Dalam UU No. 20 Tahun 2003 tentang Sistem Pendidikan Nasional pada Pasal 3 disebutkan bahwa pendidikan nasional berfungsi mengembangkan kemampuan dan membentuk karakter serta peradaban bangsa yang bermartabat dalam rangka mencerdaskan kehidupan bangsa. Pendidikan nasional bertujuan untuk berkembangnya potensi peserta didik agar menjadi manusia beriman dan bertakwa kepada Tuhan Yang Maha Esa, berakhlak mulia, sehat, berilmu, cakap, kreatif, mandiri, dan menjadi warga negara yang demokratis serta bertanggung jawab. Dari fungsi dan tujuan tersebut dapat dipahami bahwa pendidikan di setiap jenjang haruslah dilaksanakan secara sistematis untuk mencapai tujuan tersebut, termasuk dalam pembelajaran sejarah.

Tujuan pembelajaran sejarah di sekolah tidak hanya berkaitan dengan kemampuan dalam memahami materi sejarah saja, aspek afektif dan psikomotorik juga perlu diperhatikan oleh guru sejarah. Namun sayangnya hal ini sering dilupakan dalam prakteknya yang cenderung masih pada proses transfer informasi. Pembelajaran sejarah yang dirancang belum sampai pada kebermaknaan dan kebermanfaatan pada diri peserta didik. Pendidikan sejarah di level pendidikan dasar dan menengah lebih diutamakan untuk membekali peserta didik dalam mengantisipasi permasalahan kehidupan sehingga memiliki otonomi diri (Ekasari, 2017 :193). Namun kebermaknaan sejarah untuk peserta didik juga harus diperhatikan, manfaat apa yang akan diterima peserta didik dari pembelajaran sejarah untuk kehidupan sehari-hari.

Karakteristik mata pelajaran sejarah dalam kurikulum 2013 yaitu proses internalisasi nilai-nilai, pengetahuan dan keterampilan kesejarahan dari serangkaian peristiwa yang dirancang dan disusun sedemikian rupa untuk mendukung proses belajar peserta didik. Dengan demikian pembelajaran sejarah haruslah mencakup pendidikan 
nilai, maka pembelajaran sejarah harus diarahkan untuk memahami dan menghayati nilai-nilai karakter yang tercermin dalam setiap cerita sejarah. Menurut Hamid Hasan (2012) materi pendidikan sejarah sangat potensial untuk mengembangkan pendidikan karakter bangsa, oleh karena itu materi pendidikan sejarah harus mencakup materi yang dapat menjelaskan kenyataan kehidupan masa kini, arah perubahan yang sedang terjadi, tradisi, nilai, moral, semangat perjuangan hidup di masyarakat ketika suatu peristiwa sejarah terjadi dan masih diwariskan hingga masa kini. (Susanto, 2014:37).

\section{METODE}

Di dalam suatu penelitian ilmiah, diperlukan suatu metode tertentu yang sesuai dengan objek penelitian. Metode penelitian merupakan suatu cara untuk mencapai tujuan penelitian dengan menggunakan teknik tertentu. Dengan kata lain, metode adalah cara atau jalan sehubungan dengan upaya ilmiah yang menyangkut masalah kerja, yaitu cara untuk dapat memahami objek yang menjadi sasaran ilmu yang bersangkutan (Koentjaraningrat, 1983: 7). Pada penelitian ini, peneliti menggunakan jenis penelitian Studi Kepustakaan (Library Research) yang merupakan penelitian dengan mengumpulkan informasi dan data dengan mengadakan penelaahan terhadap bukubuku, literatur, dan juga jurnal yang didapati dari perpustakaan digital di internet.Objek dalam makalah ini adalah pengamalan nilai-nilai Pancasila dalam pendidikan, dimana pendidikan ini berfokus pada pembelajaran sejarah di Indonesia. Sedangkan subjeknya adalah pelajar atau peserta didik. Jenis data yang digunakan dalam penelitian ini adalah data sekunder yang diperoleh dari berbagai macam sumber yang ada untuk mendukung pengamatan. Datanya berupa laporan atau jurnal yang terkait dengan materi yang dibahas, yaitu pendidikan nilai Pancasila dalam pembelajaran sejarah.

\section{HASIL DAN PEMBAHASAN \\ Konsep dan Implementasi Pendidikan Multikultural}

Pendidikan multikultural sesungguhnya belum terlalu jelas hingga saat ini, masih banyak pakar pendidikan yang memperdebatkan masalah tersebut. Namun demikian, bukan berarti bahwa definisi pendidikan multikultural tidak ada atau tidak jelas. Sonia Nieto menjelaskan, pendidikan multikultural adalah suatu langkah dari perubahan besar sekolah dan pendidikan dasar untuk semua siswa. Pendidikan multikultural berkaitan dengan pengakuan nilai-nilai, gaya hidup, dan gambaran simbolis (Hopkins, 2011: 1).

Pendidikan multikultural secara etimologis terdiri dari dua terma, yaitu pendidikan dan multikultural. Pendidikan merupakan usaha sadar dan terencana untuk mewujudkan suasana belajar agar peserta didik secara aktif mengembangkan potensi dirinya untuk memiliki kekuatan spiritual keagamaan, pengendalian diri, kepribadian, kecerdasan, akhlak mulia, serta keterampilan yang diperlukan dirinya, masyarakat bangsa dan negara. Sedangkan secara terminologis, pendidikan multikultural merupakan proses pengembangan seluruh potensi manusia yang menghargai pluralitas dan heterogenitas sebagai konsekuensi keragaman budaya, etnis, suku, dan aliran (agama), ekonomi, sosial dan politik (Adhani, 2014: 113). Menurut Banks (1994), tujuan utama dari pendidikan multikultur agar mampu merubah sekolah sehingga semua siswa akan belajar tentang pengetahuan, sikap dan kebutuhan keahlian untuk diterapkan dalam negara dan dunia yang memiliki bermacam ras dan budaya. Di Indonesia, pendidikan multikultural relatif baru dikenal sebagai suatu pendekatan yang dianggap lebih sesuai bagi masyarakat Indonesia yang heterogen, terlebih pada masa otonomi dan desentralisasi yang baru dilakukan (Susongko, 2011: 2).

Pendidikan multikultural sebagai wacana baru di Indonesia dapat dilaksanakan tidak hanya melalui pendidikan formal namun juga dapat diimplementasikan dalam kehidupan masyarakat maupun dalam keluarga (pendidikan nonformal dan informal).Dalam pendidikan formal pendidikan multikultural ini tidak harus menjadi mata pelajaran sendiri namun dapat diintegrasikan dalam mata pelajaran lain yang 
mempunyai tujuan pendidikan yang sama. Pada pendidikan non formal wacana ini dapat disosialisasikan melalui pelatihan-pelatihan dengan model pembelajaran yang mengedepankan multikultural berupa penghormatan terhadap perbedaan baik ras suku, maupun agama antar anggota masyarakat (Susongko, 2011: 2-3).

Dalam pendidikan multikultural, ada dimensi-dimensi yang harus diperhatikan. Setidaknya ada lima dimensi pendidikan multikultural yang saling berkaitan, diantaranya (Banks, 1994):

1. Mengintegrasikan berbagai budaya dan kelompok untuk mengilustrasikan konsep mendasar, generalisasi, dan teori dalam mata pelajaran

2. Membawa siswa untuk memahami implikasi budaya ke dalam sebuah mata pelajaran

3.Menyesuaikan metode pengajaran dengan cara belajar siswa dalam rangka memfasilitasi prestasi akademik

4. Mengidintifikasi karakteristik ras siswa dan menentukan metode pengajarannya 5.Melatih kelompok untuk berpartisipasi dalam berbagai kegiatan, berinteraksi dengan seluruh siswa dan staf yang berbeda ras dan etnis untuk menciptakan budaya akademik.

Prosedur yang seharusnya ditempuh dalam implementasi pendidikan multikultur di Indonesia adalah, penyiapan kurikulum, yakni menyisipkan berbagai kompetensi yang harus dimiliki siswa tentang multikulturalisme pada mata pelajaran yang relevan, karena multikulturalisme baru sebuah gerakan dan belum menjadi sebuah ilmu yang komprehensif. Kemudian dilanjutkan dengan perumusan berbagai materi yang sesuai dengan kompetensi yang hendak dicapai, dan diikuti dengan rumusan proses pembelajaran yang lebih memberikan peluang bagi para siswa untuk pembinaan dan pengembangan sikap, di samping pengetahuan dan keterampilan sosial yang terkait dengan upaya pengembangan sikap multikulturalistik (Rosyada, 2014: 4).

\section{Tantangan Pendidikan Multikultural di Indonesia}

Multikulturalisme adalah respon terhadap realitas, dimana masyarakat selalu menjadi plural dan tidak monolitik. Keanekaragaman membawa perbedaan dan dapat berujung pada konflik. Namun, bukan berarti konflik selalu disebabkan oleh perbedaan. Dari sudut pandang agama, keragaman, keyakinan, budaya, dan pandangan hidup penting untuk diangkat kembali mengingat penganut agama-agama di Indonesia masih awam, sehingga sangat rawan dengan konflik dan kekerasan (Ibrahim, 2008: 118).

Ada dua fakta yang perlu dikemukakan sehubungan dengan merebaknya konflik dalam masyarakat yang berlarut-larut. Pertama, dalam sejarahnya pertemuan agamaagama dan perbenturan kadang-kadang tidak terelakkan, karena masalah agama lebih sensitif dibanding dengan yang lainnya. Kedua, bila diamati dalam kurun waktu tiga dekade di penghujung abad 20 dan awal abad 21, ada dua gejala sosial yang muncul ke permukaan, yaitu fenomena sosiokultural yang menggejala pada masyarakat postmodern dan fenomena transmisi global seperangkat "kesadaran dan institusi" modern (sosial, ekonomi, dan budaya) hingga menyentuh masyarakat yang belum modern yang disebut juga "globalisasi" (Jandra, 2005: 232-233).

Dalam mengimplementasikan pendidikan multikultural di sekolah akan mengalami hambatan atau tantangan dalam pelaksanaannya, hal-hal ini harus diperhatikan sejak awal dan diantisipasi, diantaranya (Arifudin, 1970: 6):

1. Perbedaan pemaknaan terhadap pendidikan multikultural

$\mathrm{Hal}$ ini akan menyebabkan perbedaan dalam mengimplementasikannya, akrena mutikultural sering dimaknai hanya sebagai multi etnis. Pendidikan mutikultural mencakup arti dan tujuan untuk mencapai sikap toleransi, menghargai keragaman dan perbedaan, menjunjung tinggi nilai kemanusiaan, menyukai hidup damai, dan demokratis.

2. munculnya gejala diskontinuitas 
Peserta didik memiliki latar belakang sosiokultural yang berbeda, sehingga dapat dimungkinkan mereka mengalami kesulitan untuk beradaptasi di sekolah. Di sinilah seorang para pengajar dan pendidik perlu memahami dan mengetahui latar belakang sosiokultural peserta didik sampai pada tipe kemampuan berpikir dan kemampuan menghayati sesuatu di lingkungan.

3. Rendahnya komitmen berbagai pihak

Berhasilnya implementasi pendidikan multikultural sangat bergantung pada seberapa besar keinginan dan kepedulian masyarakat sekolah untuk melaksanakannya, terutama oleh guru. Bila berbagai elemen yang terlibat dalam pendidikan menyadari akan kebijakan pendidikan di Indonesia untuk menghendaki terwujudnya masyarakat madani, maka sebenarnya komitmen tinggi untuk pelaksanaan pendidikan multikultural akan mudah dicapai. Sebab nilai-nilai masyarakat madani itu yang ingin ditanamkan pada siswa melalui pendidikan multikultural.

4. Kebijakan-kebijakan yang suka akan keseragaman

Sistem pendidikan yang sejak dulu bersifat sentralistis berpengaruh pada sistem perilaku dan tindakan orang-orang yang ada di dunia pendidikan, sehingga sulit menghargai dan mengakui keragaman dan perbedaan. Oleh karena itu, pelaksanaan pendidikan multikultural sarat dengan nilai penghargaan terhadap rasa kemanusiaan, perbedaan, dan keragaman akan menjadi kurang disukai dan kurang dianggap penting.

Oleh sebab itu, strategi pendidikan multikultural perlu dijabarkan dalam implikasi di sekolah. Dari para ahli maka pendidikan multikultural dapat diimplikasikan dalam dunia pendidikan sebagai berikut (Najmina, 2018: 4):

1.Membangun paradigma keberagaman inklusif di lingkungan sekolah

2.Menghargai keragaman bahasa di sekolah

3. Membangun sikap sensitif gender di sekolah

4.Membangun pemahaman kritis dan empati terhadap ketidakadilan serta perbedaan sosial

5. Membangun sikap antideskriminasi etnis

6.Menghargai perbedaan kemampuan

7.Menghargai perbedaan umurlnovasi pembelajaran sejarah diperlukan dalam mata pelajaran sejarah untuk membentuk karakter peserta didik dengan melakukannya secara menyeluruh dan terpadu dimulai dari perencanaan, strategi pembelajaran, dan evaluasi pembelajaran (Susanto, 2014: 37-38).

1. Pada tahap perencanaan, pengorganisasian materi harus lebih ditekankan untuk penanaman nilai-nilai karakter sesuai dengan Standar Kompetensi dan Kompetensi Dasar.

2. Dalam strategi pembelajaran, pembelajaran sebaiknya lebih diarahkan untuk rekonstruksi nilai-nilai karakter melalui cerita sejarah. Dalam kegiatan pembelajaran, fokus utama bukanlah ekspositori oleh guru, tetapi menekankan pada inquiri. Peserta didik diarahkan untuk menemukan nilai-nilai karakter yang kemudian diaplikasikan dalam kehidupan sehari-hari.

3. Evaluasi pembelajaran sejarah menekankan pada penilaian proses dan hasil belajar siswa, yang mencakup kecakapan akademik, kesadaran sejarah, dan nasionalisme. Sehingga evaluasi tidak hanya mencakup aspek kognitif, akan tetapi juga afektif.

Langkah-langkah tersebut diharapkan menjadikan pembelajaran sejarah dapat lebih bermakna dan dapat berperan optimal sebagai upaya penyadaran terhadap jati diri bangsa sehingga dapat membentuk karakter peserta didik. 


\section{SIMPULAN}

Pendidikan multikultural relatif baru dikenal sebagai suatu pendekatan yang dianggap lebih sesuai bagi masyarakat Indonesia yang heterogen. Pendidikan multikultural ini sangatlah berguna untuk peserta didik yang memiliki latar belakang yang berbeda, namun implementasinya masih kurang dilakukan oleh pengajar dan pendidik. Konflik yang muncul di kalangan pelajar tidak jauh dari latar belakang mereka yang berbeda, baik itu agama, suku, budaya, ataupun bahasa. Tentunya akan ada banyak tantangan dalam mengimplementasikannya seperti yang sudah disebutkan, namun jika pendidikan multikultural dapat diterapkan oleh semua sekolah di Indonesia, maka konflik sosial yang terjadi dapat mampu ditekan. Dengan adanya implementasi pendidikan yang berwawasan multikultural, diharapkan pula dapat membantu siswa memahami, menerima, dan menghargai orang laun yang berbeda suku, budaya, dan nilai kepribadian.

Mengingat setiap peserta didik tidak semuanya dari latar belakang yang sama, pendidikan multikultural ini sangatlah berguna, hanya disayangkan implementasinya masih kurang dilakukan oleh sekolah dan pengajar dan pendidik. Sebab, konflik yang muncul di kalangan siswa atau remaja tidak jauh dari latar belakang mereka yang berbeda, baik itu agama, suku, budaya, ataupun bahasa. Dalam kurikulum 2013 sudah diselipkan pendidikan multikultural, hanya saja hal tersebut masih menjadi wacana dan tidak terlalu diperhatikan oleh pengajar dan pendidik. Wujud dari pendidikan multikultural tersebut dapat dilihat dalam buku-buku teks penunjang dimana guru dituntut untuk dapat mengintegrasikan multikultural pada mata pelajaran yang diampunya. Memang akan ada banyak tantangan dalam mengimplementasikannya seperti yang sudah disebutkan, namun jika pendidikan multikultural dapat diterapkan oleh semua sekolah di Indonesia, maka konflik sosial yang terjadi dapat mampu ditekan. Juga dengan adanya implementasi pendidikan yang berwawasan multikultural, diharapkan pula dapat membantu siswa memahami, menerima, dan menghargai orang laun yang berbeda suku, budaya, dan nilai kepribadian.

\section{DAFTAR PUSTAKA}

Adhani, Y. (2014). Konsep Pendidikan Multikultural Sebagai Sarana Alternatif Pencegahan Konflik. SOSIO DIDAKTIKA: Social Science Education Journal, 1(1). https://doi.org/10.15408/sd.v1i1.1211

Agung, D. A. G. (2017). Keragaman Keberagaman (Sebuah Kodrati Kehidupan Berbangsa dan Bernegara Berdasarkan Pancasila). Sejarah Dan Budaya : Jurnal Sejarah, Budaya, Dan Pengajarannya, 11(2), 151-159. https://doi.org/10.17977/um020v11i22017p151

Ambarudin, R. I. (2016). Pendidikan multikultural untuk membangun bangsa yang nasionalis religius. Jurnal Civics: Media Kajian Kewarganegaraan, 13(1). https://doi.org/10.21831/civics.v13i1.11075

Andarwati, M. (2017). Menguatkan Karakter Bhineka Tunggal Ika Melalui Pembelajaran Sejarah di Kelas. Sejarah Dan Budaya: Jurnal Sejarah, Budaya, Dan Pengajarannya, 11(2), 174-179. https://doi.org/10.17977/um020v11i22017p174

Arifudin, I. (1970). Urgensi Implementasi Pendidikan Multikultural di Sekolah. INSANIA: Jurnal Pemikiran Alternatif Kependidikan, 12(2), 220-233. https://doi.org/10.24090/insania.v12i2.252

Banks, J. (1994). An Introduction to Multicultural Education. In Journal of Teacher Education, Vol. 45, Issue 5. 
Ekasari, Putri Nur. (2017). Pembelajaran Berbasis Nilai pada Mata Pelajaran Sejarah Melalui Model VCT (Value Clarification Technique). SEJARAH DAN BUDAYA, Vol. 11 (2), 192-198.

Hopkins-gillispie, D., \& Ph, D. (2011). Curriculum \& Schooling: Multiculturalism, Critical Multiculturalism and Critical Pedagogy. 4(1999), 1-10.

Ibrahim, R. (2008). Pendidikan Multikultural: Upaya Meminimalisir Konflik dalam Era $\begin{array}{llll}\text { Pluralitas } & \text { Agama. } & \text { El-Tarbawi, } & 115-127 .\end{array}$ https://doi.org/10.20885/tarbawi.vol1.iss1.art9

Najmina, N. (2018). Pendidikan Multikultural Dalam Membentuk Karakter Bangsa Indonesia. Jupiis: Jurnal Pendidikan IImu-IImu Sosial, 10(1), 52. https://doi.org/10.24114/jupiis.v10i1.8389

Rosyada, D. (2014). Pendidikan Multikultural Di Indonesia Sebuah Pandangan Konsepsional. SOSIO DIDAKTIKA: Social Science Education Journal, 1(1). https://doi.org/10.15408/sd.v1i1.1200

Susanto, Heri. (2014). Seputar Pembelajaran Sejarah. Yogyakarta: Aswaja Pressindo Susongko, P. (2011). PENGEMBANGAN STANDAR KOMPETENSI PADA PENDIDIKAN MULTIKULTURAL di SEKOLAH. Jurnal Cakrawala Pendidikan, $6(2), 1-9$. 